\title{
IDENTIFIKASI KONFLIK PEREBUTAN TANAH ADAT DI DAERAH LAHAN BASAH KABUPATEN BANJAR
}

\author{
Acep Supriadi Wahyu \\ Mariatul Kiptiah \\ Program Studi Pendidikan Pancasila dan Kewarganegaraan Univ. Lambung Mangkurat \\ Jl. Brigjen. H. Hasan Basri Banjarmasin \\ email: profwahyu@gmail.com
}

\begin{abstract}
Conflict over customary land dispute in the area of wetlands and located in South Kalimantan in order of importance of business expansion by certain groups increasingly rife. The results of the research in the first year indicates that the land-related conflicts in wetland areas associated with layered certificate and between the seal and the certificate in the village of Gambut District of Banjar Regency. Generally, conflicts become apparent when peat lands are uncultivated land previously held a high place in the economy due to the access road. High-value economy is usually associated with the interests of residential, business, and other economic interests. The next approach in this research uses a qualitative approach with descriptive methods. The population derived from the conflicts over indigenous land in wetland areas Banjar regency with the sampling technique is purposive sampling. In general, the Focus Group Discussion (FGD) for two events form the basis for formulating a model of conflict resolution of land in wetland areas. Land conflicts that stem from overlapping certificates, certificates and seals both for personal as well as public and indigenous land has led to the completion of both litigation and non litigation. Outcomes of this study is to create a model of conflict resolution of land in wetland areas in Banjar district.
\end{abstract}

Keyword: wetlands, land conflict, conflict resolution

\begin{abstract}
Abstrak: Konflik tentang perebutan tanah adat di daerah lahan basah dan strategis di Kalimantan Selatan dalam rangka kepentingan perluasan lahan bisnis oleh kelompok tertentu semakin marak terjadi. Hasil penelitian di tahun ke 1 menunjukkan bahwa konflik tanah yang terkait di daerah lahan basah berhubungan dengan sertifikat berlapis dan antara segel dan sertifikat di daerah kelurahan Gambut Kecamatan Gambut Kabupaten Banjar. Umumnya, konflik menjadi muncul ketika lahan gambut yang sebelumnya adalah lahan tidur sudah bernilai tinggi secara ekonomi akibat adanya akses jalan. Bernilai tinggi secara ekonomi biasanya terkait dengan kepentingan pemukiman, usaha, dan kepentingan ekonomi lainnya. Pendekatan dalam penelitian ini selanjutnya menggunakan pendekatan kualitatif dengan metode deskriptif. Populasi yang diambil diperoleh dari daerah konflik perebutan tanah adat di daerah lahan basah Kabupaten Banjar dengan teknik samplingnya adalah purposive sampling. Secara umum, Focus Group Discussion (FGD) selama dua kali kegiatan menjadi dasar dalam memformulasi model penanganan konflik tanah di daerah lahan basah. Konflik tanah yang berakar dari sertifikat tumpang tindih, sertifikat dan segel baik untuk kepentingan pribadi serta umum serta tanah ulayat sudah mengarah pada penyelesaian baik litigasi maupun non litigasi. Luaran dari penelitian ini adalah membuat model penanganan konflik tanah di daerah lahan basah di Kabupaten Banjar.
\end{abstract}

Kata Kunci: lahan basah, konflik tanah, dan model penanganan

Berbicara tanah tentu berbicara tentang bagaimana setiap manusia bisa bertahan hidup karena tanah sesungguhnya menjadi tempat bagi setiap manusia untuk melakukan aktualisasi diri (UU Agraria No. 5/1960). Tanah merupakan permulaan dalam membangun kehidupan manusia. Pertahanan kehidupan manusia juga sangat dipengaruhi oleh keberadaan tanah. Tanah menjadi tempat berpijak sehingga ini pun harus dipertahankan keberlangsungannya. Pembicaraan 
tentang tanah tidak dapat dilepaskan dari agraria yang sudah lama menjadi pembahasan dari masa ke masa. Konflik agraria dalam setiap peradaban manusia menjadi warna tersendiri yang menentukan sebuah perjalanan bangsa. Konflik agraria berjalin kelindan dengan bagaimana lahan menjadi ajang kontestasi (Suhendar dan Winarni, 1998). Dengan kata lain, perebutan lahan terus menerus bermunculan. Tanah, dalam konteks ini, kemudian menjadi rebutan dan perebutan sehingga kondisi inilah yang melahirkan konflik. Umumnya, konflik tentang perebutan tanah muncul ketika ada pihak yang merasa kuat ingin menguasai tanah padahal lahan tersebut menjadi milik bersama.

Data menunjukkan bahwa di Kalimantan Timur (Kaltim) konflik agraria umumnya didominasi oleh konflik sektor perkebunan dengan jumlah 30 konflik, kemudian konflik di sektor kehutanan dengan jumlah 26 konflik, dan konflik pertambangan sebanyak 5 konflik. Konflik di sektor kehutanan, misalnya, terjadi akibat perampasan hutan adat oleh perusahaan hutan tanaman industri, padahal Kementerian Kehutanan telah menyutujui adanya hutan adat seluas 700 Ha dari 11.667 Ha di Masyarakat Adat Modang. Sementara di Kalimantan Selatan (Kalsel) konflik didominasi oleh konflik di sektor pertambangan dan perkebunan dengan skala besar dengan masing-masing 7 konflik, kemudian sektor kebijakan penataan ruang dengan 3 konflik dan 1 konflik di sektor kehutanan. Salah satu konflik perkebunan besar adalah rencana pembukaan lahan rawa secara besar-besaran di daerah rawa di beberapa kabupaten seperti Hulu Sungai Utara, Hulu Sungai Selatan, Tanah Laut dan Tapin. Ekspansi perkebunan besar selain mengancam pengurangan lahan pertanian juga mengancam mata pencaharian masyarakat di sektor perikanan air tawar. Industri ekstraktif pertambangan batu bara cukup masif di Kalimantan Selatan walaupun hanya tercatat hanya 7 konflik tapi diperkirakan jumlahnya mungkin jauh lebih besar. Salah satu konflik dengan pertambangan adalah di komunitas Dayak Deyah di Kabupaten Tabalong. Perusahaan pertambangan telah merampas lahan milik masyarakat padahal disana terdapat setidaknya ada 6 lokasi makam leluhur mereka.Kini apapun nama konflik yang memicu tersebut, maka ketika rakyat ingin merebut kembali tanahnya yang akan dirampas para perampok, hal tersebut sebetulnya dinamakan konflik restoratif (Sadikin dan Samandawai, 2007).
Selanjutnya hasil penelitian berjudul "Identifikasi Konflik Perebutan Tanah Adat di Daerah Lahan Basah Kabupaten Banjar" (Wahyu dan Mariatul Kiptiah, 2014) yang merupakan penelitian tahun ke-1 menunjukkan bahwa konflik tanah yang terkait dengan lahan basah secara lebih persisnya berada di Kelurahan Gambut dan umumnya mengenai sertifikat berlapis. Yang mendasari kemunculan konflik tanah dan adanya sertifikat berlapis adalah karena adanya akses jalan yang sebelumnya tidak ada. Tanah di daerah lahan basah kelurahan Gambut yang sebelumnya hanya merupakan lahan tidur atau dapat juga disebut Hutan Galam kemudian bernilai ekonomi tinggi pasca dibukanya akses jalan. Tanah dengan sertifikat berlapis berlokasi di sepanjang jalan A. Yani di antara Km. 7 sampai dengan Km. 18 dan Lingkar Utara.

Dengan pertimbangan itulah, maka menjadi penting untuk mendesain pola penanganan konflik tanah di daerah lahan basah di Kabupaten Banjar dalam rangka mengantisipasi konflik-konflik laten tentang tanah yang dimungkinkan muncul suatu waktu tertentu. Tujuan penulisanini adalah untuk mendeskripsikan pemetaan tahapan upaya-upaya dalam penanganan konflik tanah di daerah lahan basah Kabupaten Banjar, khususnya Kecamatan Gambut dan membuat model penanganan konflik tanah di daerah lahan basah Kabupaten Banjar, khususnya Kecamatan Gambut. Kebermanfaatan tulisan ini setidaknya mencakup dua aspek baik dalam konteks teoritis maupun praktis. Secara teoritis diharapkan dapat memberikan sebuah pandangan baru terkait pemetaan tahapan upayaupaya dalam penanganan konflik tanah di daerah lahan basah Kabupaten Banjar, khususnya Kecamatan Gambut. Secara praktis, diharapkan dapat memberikan sumbangan konkret bagi pemerintah daerah dan pusat tentang model penanganan konflik tanah di daerah lahan basah Kabupaten Banjar, khususnya Kecamatan Gambut.

Kajian ini bermaksud untuk mengindentifikasi persoalan yang dihadapi masyarakat di daerah lahan basah di Kabupaten Banjar terkait perebutan tanah adat. Pendekatan yang digunakan adalah pendekatan kualitatif deskriptif yang bertujuan untuk mengetahui dan mengamati akar konflik yang mendasari perebutan tanah adat di daerah lahan basah Kabupaten Banjar. Lokasi penelitian dilakukan di daerah lahan basah Kabupaten Banjar yang sedang terjadi konflik perebutan tanah adat. 
Populasinya adalah semua warga dengan tanah adatnya yang sedang menjadi lahan perebutan oleh pihak penguasa di daerah lahan basah Kabupaten Banjar.Penentuan sampel dilakukan dengan purposive sampling. Respondennya adalah tokoh masyarakat, ketua RT/RW, lurah Gambut, dan camat. Penelitian ini menggunakan teknik pengumpulan data berupawawancara mendalam dan observasi langsung. Analisa data adalah dengan menggunakan deskriptif-analitis, yakni menggambarkannya dan kemudian menganalisa obyek penelitian tersebut secara kritis. Setelah itu, dilakukan teknik analisis isi (content analysis).

Latar belakang konflik tanah di Kabupaten Banjar, terutama di Kelurahan Gambut adalah terkait dengan dua hal, yakni waris dan pembangunan di bidang ekonomi. Untuk konflik tanah yang bersumber dari perebutan tanah warisan, maka dilakukan dengan pendekatan kekeluargaan dimana kelurahan memfasilitasi kedua belah dalam konteks mencari jalan tengah dengan tujuan agar bisa mendamaikan dan mencari titik temu yang menyejukkan. Dengan kata lain, lurah dan atau pembakal mengundang saudara sekandung dari bapak atau ibu untuk duduk bersama dalam rangka menemukan jalan keluar. Dalam konflik perebutan tanah warisan, jalan tempuh lebih berorientasi kepada semangat bersama dan harmoni untuk tetap mempertahankan keutuhan keluarga. Oleh sebab itu, langkah pertama dengan mengundang saudara sekandung menjadi awal untuk membuka dialog. Pintu pembuka dialog tersebut kemudian diteruskan dengan meminta kedua belah pihak untuk saling menceritakan permasalahan yang ada, memulai dari sumber masalah itu muncul. Dengan menceritakan masalahnya, ini kemudian diarahkan kepada apa yang menyebabkan masalah atau pemicu kemunculan masalah tersebut.

Langkah selanjutnya adalah mendudukkan setiap persoalan secara proporsional dan memberikan tanggapan atas penyampaian kedua belah pihak juga proporsional, tidak mengundang keberpihakan karena faktor pertimbangan tertentu. Setelah memberikan umpan balik atau tanggapan balik dari pihak kelurahan atau pembakal kepada kedua belah pihak yang berkonflik dalam satu keluarga tersebut, maka kedua belah pihak selanjutnya memberikan penyampaian ulang. Langkah dan pendekatan dialog tersebut dilakukan secara berulang-ulang dalam satu kegiatan pem-fasilitasi-an hingga akar persoalan menjadi jelas serta terukur dan semua pihak bisa saling menerima pendapat masingmasing. Satu kegiatan pem-fasilitasi-an selesai, maka kedua belah pihak yang berkonflik dipersilahkan untuk melakukan perenungan secara mendalam demi kepentingan bersama. Agenda selanjutnya adalah meminta kedua belah pihak untuk menentukan jadwal pertemuan kembali. Selama masa jedah untuk menuju pertemuan selanjutnya, dipersilahkan agar kedua belah pihak membahasnya bersama keluarga terkait dengan melaporkan apa yang sudah dimusyawarahkan bersama kelurahan. Mendiskusi hasil pertemuan dengan kelurahan dalam keluarga tentunya diharapkan bisa memberikan titik terang arah penyelesaian konflik tersebut.

Selanjutnya pada pertemuan berikut dimana kelurahan melakukan fasilitasi terhadap kedua belah pihak, maka kedua belah pihak yang berkonflik tersebut menyampaikan ulang atas hasil musyawarah dengan keluarga. Umumnya, ada dua hasil atas fasilitasi kelurahan, yakni sepakat untuk sepakat mengakhiri konflik secara kekeluargaan dimana konflik tanah dianggap selesai setelah sama-sama sepakat atas kesepakatan bersama di antara kedua belah pihak dan sepakat untuk tidak sepakat dimana konflik yang tidak bisa diselesaikan di tingkat kelurahan diteruskan ke meja pengadilan agama. Ketika sudah masuk ke pengadilan agama, maka pendekatan hukum positif kemudian menjadi jalan terakhir dengan mendasarkan diri kepada ilmu waris yang kemudian lebih dikenal disebut ilmu faraidh.

Selanjutnya mengenai konflik perebutan tanah yang didasarkan pada tumpang tindih sertifikat, segel dengan sertifikat, surat kepemilikan tanah (SKT) dan sertifikat tanah yang berorietansi kepada pembangunan ekonomi sudah menjadi bagian dari posisi strategis, maka umumnya, ketika ada konflik tanah, hal ini kemudian diselesaikan secara kekeluargaan yang awalnya difasilitasi aparat kelurahan, yakni Lurah dan Ketua RT setempat. Dalam status ini, kedua belah pihak yang bersengketa kemudian dihadap-hadapkan dan diajak melakukan dialog dengan kemudian menunjukkan surat tanah yang dimiliki, misalnya segel atau sertifikat tanah dan surat-surat lain yang bisa mendukung untuk menguatkan kepemilikan. Tak hanya itu saja, proses dialog untuk menjembatani ketidakjelasan menuju kejelasan status tanah yang sedang menjadi konflik juga 
dilakukan dengan melakukan pengukuran ulang batas tanah dengan menghadirkan tetangga terdekat yang kebetulan atau tidak dekat dengan tanah yang sedang menjadi bahan konflik tersebut. Para saksi tersebut adalah tetangga kanan, kiri, depan, dan belakang yang mengitari tanah berkonflik tersebut. Dengan menggunakan pendekatan tersebut, ini diharapkan bisa memberikan upaya penjelasan. Selain itu, umur surat tanah pun kemudian menjadi pertimbangan, apakah segel, surat keterangan tanah, sertifikat tanah, dan saporadik yang lebih muncul. Dengan kondisi kemunculan yang lebih awal, ini dapat memperjelas status kepemilikan tanah dan begitu seterusnya.

Tentunya, dialog tahap satu selesai dilaksanakan dan semua pihak yang berkonflik diharapkan melakukan perenungan diri sebelum melakukan dialog kekeluargaan atas tanah konflik. Harapannya adalah di dialog tahap kedua ini kedua belah pihak sudah menemukan titik terang, apakah sepakat untuk mengakhir konflik dengan mengakui status tanah yang dimiliki oleh surat tanah, yang lebih awal muncul dan begitu seterusnya. Dengan kata lain, sepakat untuk sepakat menyelesaikan perdebatan mengenai tanah di tingkat kelurahan saja. Apabila hasil dialog tahap kedua kemudian menjadi buntu, maka biasanya akan mengundang pihak Badan Pertanahan Nasional (BPN) untuk melakukan pengukuran ulang serta mengecek status surat tanah, manakah yang lebih kuat baik secara hukum maupun secara usia surat keluarnya tanah.

Selanjutnya, yang biasa dilakukan pasca dialog kekeluargaan ketika tidak mencapai titik temu, ini kemudian dilanjutkan dengan jalur hukum, yakni pengadilan negeri. Di dalam pengadilan negeri, maka baik penggugat maupun tergugat harus mengikuti peraturan yang berlaku dalam persidangan, menunjukkan fakta-fakta hukum demi kepentingan hukum yang berlaku. Umumnya, ada beberapa hal yang dilakukan ketika sudah masuk jalur hukum. Pertama, baik tergugat maupun penggugat harus menyiapkan berkasberkas terkait untuk saling menguatkan bukti kepemilikan tanah. Bukti-bukti kepemilikan tanah tersebut kemudian dilakukan verifikasi secara administratif melalui Badan Pertanahan Nasional (BPN) sebelum dikembangkan dan dilanjutkan dengan survei lapangan. Kedua, baik tergugat maupun penggugat juga harus menghadirkan para saksi yang bisa menguatkan bukti kepemilikan tanah. Para saksi tentunya adalah orang yang paling dekat dengan daerah tanah tersebut menjadi bahan konflik. Saksi adalah yang tinggal di bagian kiri, kanan, depan, dan belakang tanah yang menjadi sengketa konflik. Ketiga, menunggu hasil dari proses hukum yang berlangsung di pengadilan negeri, siapakah yang menang (bukan dimenangkan) dengan mempertimbangkan buktibukti yang sudah ditunjukkan di sidang pengadilan.

Berdasarkan sejumlah temuan yang diperoleh dari hasil Focus Group Discussion (FGD) selama dua kali kegiatan, selanjutnya menjadi penting untuk membangun konsep baru tentang upaya-upaya dan langkah-langkah yang dapat digunakan dalam menyelesaikan konflik tanah, baik yang merupakan konflik tanah warisan, tanah ulayat, maupun konflik tanah demi kepentingan umum.

Konflik tanah dalam rentang sejarah dari waktu ke waktu tidak akan pernah hilang dan terus menerus akan menjadi bagian tak terpisahkan dari perjalanan kehidupan manusia. Manusia tanpa konflik tidak akan mampu melakukan adaptasi diri dan melakukan gerak langkah untuk terus melakukan pembenahan diri demi kepentingan kehidupan yang lebih baik baik diri maupun lingkungan sekitar. Menurut Limbong (2012), konflik pertanahan di dalam masyarakat pada umumnya memiliki hubungan tiga hal, yakni: (1) proses ekspansi dan perluasan skala akumulasi modal, baik modal domestik maupun internasional, (2) watak otoriternya negara dalam menyelesaikan kasus agraria, (3) berubahnya strategi dan orientasi pembangunan masyarakat menjadi kapitalistik.

Beberapa model penyelesaian konflik yang dapat digunakan untuk mengatasi sengketa tanah yaitu penyelesaian melalui pengadilan dan melalui luar pengadilan. Penyelesaian sengketa tanah melalui jalur pengadilan dapat dilakukan melalui beberapa tahap, yaitu mulai dari pengadilan negeri, pengadilan tinggi, kasasi, dan peninjauan kembali (PK). Pengadilan Negeri memproses perkara selama kurang lebih enam (6) bulan. Oleh karenanya, perkara tanah di tingkat pengadilan negeri sudah dipastikan memakan waktu yang cukup lama yang kemudian dapat menggantungkan perkara. Pengadilan Tinggi merupakan kelanjutan dari proses di pengadilan tinggi apabila ada pihakpihak yang merasa tidak puas dengan keputusan di pengadilan negeri. Masa berlangsungnya perkara di pengadilan tinggi juga tidak jauh berbeda dengan di pengadilan negeri dan ini kemudian semakin menambah mandeknya penyelesaian perkara. 
Pada tingkat kasasi sering juga terjadi keterlambatan dalam pemeriksaan. Untuk dapat diperiksa harus menunggu bertahun-tahun lamanya dan biasanya tidak kurang dari tiga (3) tahun sebelum akhirnya diputus dalam kasasi. Ini juga terjadi akibat antrean pemeriksaan dalam acara kasasi karena banyaknya perkara kasasi yang ditangani.Peninjauan Kembali (PK)umumnya memerlukan waktu antara 8-9 tahun sebelum perkara ini tiba pada taraf dapat dilakukan eksekusi oleh pengadilan negeri.

Penyelesaian perkara melalui luar pengadilan dapat dilakukan dengan musyawar (negotiation), konsiliasi, mediasi, dan arbitrase. Negosiasi merupakan fact of life dan setiap orang melakukan negosiasi untuk mendapatkan apa yang diinginkan oleh orang lain. Negosiasi berasal dari kata bahasa Inggris, negotiation yang berarti berunding, bermusyawarah atau bermufakat. Penyelesaian secara musyawarah mufakat juga dapat dikenal dengan sebutan penyelesaian secara bipartit, yakni penyelesaian yang dilakukan oleh para pihak yang sedang berselisih dan orang yang mengadakan perundingan disebut negotiator. Menurut Goodpaster (1993), negosiasi adalah suatu proses interaksi dan komunikasi dinamis serta beragam dengan tujuan menyelesaikan atau mengurangi persengketaan atau perselisihan. Sedangkan Kanowitz sebagaimana dikutip Wijaya (2001) mengatakan bahwa negosiasi itu sendiri dapat berjalan sukses ketika melibatkan beberapa hal penting: (1) kekuatan dari pengetahuan dan keterampilan; (2) kekuatan dari hubungan yang baik; (3) kekuatan dari alternatif yang baik dalam negosiasi; (4) kekuatan untuk mencapai penyelesaian yang elegan; (5) kekuasaan legitimasi; dan (6) kekuatan komitmen.

Konsiliasi merupakan bentuk pengendalian konflik sosial utama. Pengendalian ini terwujud melalui lembaga tertentu yang memungkinkan tumbuhnya pola diskusi dan pengambilan keputusan. Dalam bentuk konsiliasi, konflik pertanahan diselesaikan melalui parlemen dimana kedua belah pihak berdiskusi dan berdebar secara terbuka untuk mencapai kesepakatan.Orang yang berkonsiliasi disebut konsiliator dan yang bersangkutan terdaftar di kantor yang berwenang menangani masalah pertanahan. Konsiliator harus dapat menyelesaikan perselisihan tersebut paling lama tiga puluh hari kerja sejak menerima permintaan penyelesaian konflik. Sehubungan dengan penyelesaian konflik melalui konsiliasi, maka lembaga konsiliasi harus memenuhi hal-hal sebagai berikut: (1) bersifat otonom dan independen; (2) bersifat monopolistis atau hanya lembaga itulah yang berfungsi menyelesaikan konflik demikian; (3) mampu mengikat kepentingan semua golongan; dan (4) bersifat demokratis.

Mediasi merupakan pengendalian konflik yang dilakukan dengan cara membuat konsensus di antara dua pihak yang berkonflik untuk mencari pihak ketiga yang berkedudukan netral sebagai mediator dalam penyelesaian konflik. Mediator wajib menyelesaikan tugasnya paling lama 30 hari kerja sejak menerima pendaftaran konflik dari para pihak

Arbitrase merupakan pengendalian konflik yang dilakukan dengan cara kedua belah pihak yang bertentangan sepakat untuk menerima atau terpaksa akan hadirnya pihak ketiga yang akan memberikan keputusan bagi mereka dalam menyelesaikan konflik tersebut. Dalam penyelesaian secara arbitrase, kedua belah pihal sepakat untuk mendapatkan keputusan yang bersifat legal sebagai jalan keluar. Selayaknya kasus perdata di pengadilan, arbitrase termasuk penyelesaian kasus pertanahan, ada Penggugat dan Tergugat. Bedanya adalah disebut Pemohon dan Termohon. Secara umum, proses persidangan arbitrase dapat melalui beberapa tahap, yakni mulai dari upaya damai, jawaban Termohon, tanggapan Pemohon, pemeriksaan bukti, keterangan saksi dan ahli, kesimpulan akhir para pihak dan terakhir adalah pembacaan putusan. Putusan arbitrase bersifat final, mempunyai kekuatan hukum tetap serta mengikat para pihak. Dengan demikian, putusan arbitrase tidak dapat diajukan banding, kasasi atau peninjauan kembali.

\section{PENYELESAIAN SENGKETA TANAH ULAYAT}

Konflik tanah hak ulayat pada prinsipnya dapat diselesaikan melalui cara non litigasi atau penyelesaian sengketa alternatif. Secara umum, terbagi menjadi tiga bagian penting, yaitu tahap musyawarah, pelaksanaan hasil musyawarah, dan penutupan hasil musyawarah. Tahap musyawarah bertujuan untuk: (a) menentukan siapa yang akan menjadi juru penengah yang bertugas untuk melakukan pemahaman terhadap sengketa yang terjadi, penentuan tempat penyelesaian, waktu dan pihak-pihak lain yang akan dilibatkan serta hal-hal 
lain untuk mendukung musyawarah, (b) meminta keterangan dari pihak Pemohon/Penggugat dan Termohon/Tergugat berkaitan dengan sengketa serta mendengar keterangan dari pasa saksi yang berasal dari pihak Pemohon dan Termohon, dan (c) menyimpulkan pembicaraan, membuat surat pernyataan damai, penandatanganan kesepakatan oleh para pihak yang bersengketa (bila sudah disepakati), saksi dan penutupan musyawarah.

Tahap pelaksanaan hasil musyawarah, para pihak akan melaksanakan kesepakatan yang sudah dibuat secara suka rela. Tahap penutupan musyawarah, musyawarah akan ditutup oleh pihak yang berkompeten dan biasanya dilakukan oleh pemimpin musyawarah.

\section{PENYELESAIAN SENGKETA TANAH UNTUK KEPENTINGAN UMUM}

Konflik tanah terkait kepentingan umum sering melahirkan dampak sosial yang tidak sedikit baik secara ekonomi, sosial dan lain sejenisnya. Oleh karenanya, diperlukan strategi untuk mereduksi dampak negatif dari konflik tanah untuk kepentingan umum. Ini harus diawali dari perubahan cara pandang yang biasanya selalu menyebut ganti rugi menjadi kompensasi. Ganti rugi selama ini dimaknai bahwa pemilik hak atas tanah telah merugi sebelum melepaskan tanahnya untuk kepentingan umum.

Sementara kompensasi lebih bermakna positif, yakni balasan atau imbalan untuk tanah yang dibebaskan. Ada dua bentuk kompensasi yang umumnya dilakukan, yakni uang dan non uang atau bersifat non fisik. Untuk uang sesuai dengan jumlah yang harus diterima, hal tersebut merupakan sesuatu yang bisa dihitung secara matematis dengan

\section{DAFTAR RUJUKAN}

Gautama, Sudargo. 1999. Undang-Undang Arbritase Baru 1999. Bandung: Penerbit Citra Aditya Bakti.

Goodpaster, Garry. 1993. Negosiasi dan Mediasi: sebuah Pedoman Negosiasi dan Penyelesaian Sengketa Melalui Negosiasi. Jakarta: Penerbit Elips Project. Limbong, Bernhard. 2012. Konflik Pertanahan. Jakarta: Pustaka Margaretha.

Sadikin dan Sofwan Samandawai. 2007. Konflik Kesehariaan di Pedesaan Jawa. Bandung: AKATIGA. pendekatan ekonomi. Namun untuk non fisik, ini lebih dekat dengan pendekatan sosiologis. Bentuk kompensasi non fisik adalah sebagai berikut: (1) pembangunan infrastruktur pemukiman baru yang memadai seperti jalan dan transportasi umum, pelistrikan, dan lain-lain; (2) pembangunan sarana rekreasi seperti taman umum, tempat pertemuan umum, dan lain sejenisnya; (3) akses ke tempat strategis, seperti terminal, pasar, sekolah, dan lain sejenisnya; (4) pembangunan daerah tangkapan air yang meliputi pengelolaan sumber DAS, penghutanan kembali, dan lain sejenisnya.

\section{SIMPULAN}

Konflik perebutan tanah adat di daerah lahan basah di Kabupaten Banjar khususnya dilatarbelakangi oleh masalah waris dan pembangnan di bidang ekonomi. Secara umum konflik tersebut dapat diselesaikan dengan model penyelesaian melalui pengadilan dan melalui luar pengadilan disesuaikan dengan jenis permasalahannya. Penyelesaian sengketa tanah melalui jalur pengadilan dapat dilakukan melalui beberapa tahap, yaitu mulai dari pengadilan negeri, pengadilan tinggi, kasasi, dan peninjauan kembali (PK). Sedangkan penyelesaian perkara melalui luar pengadilan dapat dilakukan dengan musyawar (negotiation), konsiliasi, mediasi, dan arbitrase. Penyelesaian sengketa tanah ulayat dilakukan dengan cara non litigasi atau penyelesaian sengketa alternatif. Tahapan yang dilakukan adalah musyawarah, pelaksanaan hasil musyawarah dan penutup musyawarah. Sedangkan berkaitan dengan sengketa tanah untuk kepentingan umum diselesaikan dengan pemberian komisi yang sesuai dengan kesepakatan antara pihak-pihak yang berkepentingan.

Suhendar, Endang dan Yohana Budi Winarni. Petani dan Konflik Agraria. Bandung: AKATIGA.

Wijaya, Mahendra. 2001. Mediasi dan Negosiasi yang Efektif dalam Resolusi Konflik, Makalah Pelatihan ADR yang diselenggarakan Pusat Penelitian Lingkungan Hidup, Lembaga Penelitian UNS, Sukarakarta, 9 Oktober-5 Nopember. 